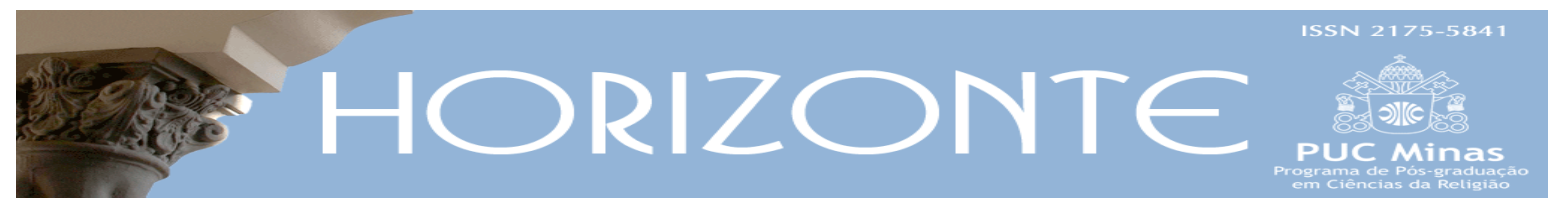

Dossiê: Religião, Direitos Humanos e Direitos da Natureza - Artigo Original ๑。

\title{
A luta pela terra no Brasil: sinal da passagem de Deus
}

\author{
The struggle for land in Brazil: a sign of the passage of God
}

Jaldemir Vitório*

\begin{abstract}
Resumo
O tema da posse e do usufruto da terra no Brasil tornou-se problema desde a chegada dos conquistadores portugueses, no início do séc. XVI. Arrancada das mãos dos habitantes primitivos do solo brasileiro, a propriedade fundiária converteu-se em assunto da Coroa Portuguesa, que transformou sua nova colônia em reservatório de inesgotáveis recursos naturais. As lutas para superar a exploração dos colonizadores começaram desde cedo, numa tentativa de dar à terra sua destinação social, para além da visão mercantilista europeia. O Movimento dos Trabalhadores Rurais Sem Terra (MST) inscreve-se numa larga epopeia de luta pela terra, numa guerra sem trégua contra o latifúndio, tendo no horizonte a utopia do acesso de todos à terra, de modo especial, quem dela depende para trabalhar, produzir e sobreviver, na contramão do agrobusiness e sua ação destruidora do solo e dos recursos naturais. Uma leitura teológica da ação MST, tendo os Direitos Humanos e os Direitos da Natureza como pano de fundo, detecta, nas entrelinhas do movimento, os sinais da passagem de Deus, como na história do Povo de Israel, libertado da terra da escravidão e conduzido à terra da fraternidade.
\end{abstract}

Palavras chaves: Movimento dos Trabalhadores Rurais Sem Terra; Latifúndio; Reforma Agrária; Teologia; Fé; Direitos Humanos.

\begin{abstract}
The theme of land possession and usufruct in Brazil became a problem upon the arrival of the Portuguese conquerors at the beginning of the 16th century. Taken violently from the hands of the native inhabitants of Brazilian soil, land ownership became the subject of the Portuguese Crown, which transformed its new colony into a reservoir of inexhaustible natural resources. The struggles to overcome the exploitation of the colonizers began early, in an attempt to give the land its social destination, beyond the European mercantilist vision. The Landless Rural Workers' Movement (MST) is part of a long epic struggle for land, in a tireless war against the private land ownership, maintaining always in its horizon the utopia of access to land, especially for those who depend on it to work, produce and survive, going explicitly against agrobusiness and its destruction of soil and natural resources. A theological reading of MST, with Human Rights and the Rights of Nature as the background, detects, in the midst of the movement, signs of the passage of God, as was experienced in the history of the People of Israel who were liberated from the land of slavery and led to the land of brotherhood.
\end{abstract}

Keywords: Movement of Landless Rural Workers; Land Ownership; Agrarian Reform; Theology; Faith; Human Rights.

Artigo submetido em 07 de março de 2017 e aprovado em 27 de agosto de 2017.

* Doutor em Teologia pela PUC-Rio (1995), professor titular da FAJE. Tem experiência na área de Teologia Bíblica, com ênfase em Literatura Profética, na Literatura Sapiencial e no Evangelho de Mateus. País de Origem: Brasil. E-mail: jvitoriosj@faculdadejesuita.edu.br

Horizonte, Belo Horizonte, v. 15, n. 47, p. 797-827, jul./set. 2017 - ISSN 2175-5841 


\section{Introdução}

Ao discursar no II Encontro Mundial dos Movimentos Populares, em Santa Cruz de la Sierra, Bolívia, em o9 de junho de 2015, o Papa Francisco proclamou: “A Bíblia lembra-nos que Deus escuta o clamor do seu povo e também eu quero voltar a unir a minha voz à vossa: terra, teto e trabalho para todos os nossos irmãos e irmãs. Disse-o e repito: são direitos sagrados. Vale a pena, vale a pena lutar por eles” (FRANCISCO, 2015b).

Num encontro anterior, em Roma, com o mesmo grupo de movimentos populares, o Papa Francisco havia dito que via “com tristeza cada vez mais longe da maioria: terra, teto e trabalho. [...] Terra, teto e trabalho - isso pelo que vocês lutam - são direitos sagrados” (FRANCISCO, 2014)ํ․

\section{O Papa preocupava-se com}

a erradicação de tantos irmãos camponeses que sofrem o desenraizamento, e não por guerras ou desastres naturais. [...] Essa dolorosa separação não é só física, mas também existencial e espiritual, porque há uma relação com a terra que está pondo a comunidade rural e seu modo de vida peculiar em notória decadência e até em risco de extinção (FRANCISCO, 2014).

As palavras recentes do Papa chamam a atenção para um problema global: a posse e o usufruto da terra, como condição para que tantos seres humanos realizem a vocação de guardiões da terra, da qual dependem para sobreviver.

O fenômeno do latifúndio e do agrobusiness geram multidões de sem-terra, fadados a uma vida subumana. Esse contexto fundiário sombrio permite-nos considerar toda e qualquer luta pela posse da terra, enquanto superação da iníqua distribuição dos bens desse mundo, como passagem de Deus, em vista da construção de um mundo onde a justiça e a fraternidade sejam os alicerces das

\footnotetext{
${ }^{1}$ No III Encontro Mundial dos Movimentos Populares, realizado no Vaticano, em seu discurso de 5/11/2016, o Papa Francisco acrescentou à temática da terra, teto e trabalho, "o drama dos migrantes, dos refugiados e dos deslocados", que, a seu modo, tem a ver com a privação da posse e do usufruto da terra (FRANCISCO, 2016).
}

Horizonte, Belo Horizonte, v. 15, n. 47, p. 797-827, jul./set. 2017 - ISSN 2175-5841 
relações humanas. E o sagrado direito de os camponeses e agricultores terem acesso à propriedade da terra seja respeitado.

O Movimento dos Trabalhadores Rurais Sem Terra (MST) construiu, nas últimas décadas, uma trajetória de luta contra o latifúndio, chaga aberta na realidade fundiária brasileira, já nos albores do que seria o Brasil. Entre tantas análises do MST - sociológica, política, econômica e ideológica -, é possível analisá-lo sob o aspecto teológico e verificar, em seus meandros, a presença invisível de Deus, agindo por diferentes mediações, para fazer "o direito brotar como fonte e a justiça correr como riacho que não seca” (Am 5,24). A história ininterrupta de luta contra um monstro de sete cabeças constrói-se em meio a vitórias e fracassos. Importa, porém, o fato de a malignidade e a truculência do latifúndio e do capital jamais serem suficientemente fortes para dobrar a fibra de quem deseja uma sociedade diferente. Na resistência dos agricultores e agricultoras pobres e, muitas vezes, analfabetos, pode-se discernir a presença de uma fé inabalável, encarnação de Deus na história.

Este texto pretende explorar o rico filão teológico do MST, quiçá despercebido por suas lideranças, mais preocupadas com a dimensão ideológica, fundamental para a condução do processo de conquista da terra. O primeiro passo esboçará o tema da posse da terra no Brasil, desde a invasão portuguesa até nossos dias. Será usado o termo "invasão", pois "descobrimento" corresponde à perspectiva dos europeus que chegaram em terras brasileiras, no séc. XVI; “invasão" é leitura na perspectiva dos aborígenes, seus moradores desde tempos imemoriais. O segundo passo mostrará como, desde a chegada dos invasores, houve resistência ao processo de colonização implantado, em detrimento dos moradores da terra e de quem dependia dela para sobreviver. O terceiro passo focará a reforma agrária, ideal continuamente frustrado pelo latifúndio. O quarto passo abordará o MST, movimento de camponeses em busca de garantir o direito de acesso e usufruto da terra. O quinto passo explicitará a luta paradigmática pela terra, na Bíblia, protótipo e inspiração para quem luta pela terra inspirado pela fé. 
O sexto passo falará da presença de Deus em meio aos conflitos fundiários, como teologia da passagem de Deus pelo solo brasileiro, nas lutas do MST. A conclusão evocará a "terra sem males", sonho de quantos anseiam pela posse da terra para cultivá-la e dela extrair o sustento.

O teológico se mesclará com a realidade em seus multifacéticos aspectos. Trata-se de discernir o rosto do Deus Libertador, caminhando com seu povo, nesse emaranhado. Assim acontece a História da Salvação, construída como luta pela garantia dos Direitos Humanos e, mais amplamente, pelos Direitos da Natureza.

\section{A posse da terra no Brasil: da invasão portuguesa a nossos dias}

A questão fundiária começa quando os portugueses pisam o solo brasileiro. Por volta de 1500, a população nativa somava cerca de quatro milhões de indígenas, sem que se possa afirmar com exatidão ${ }^{2}$. Depois de estarem à beira do extermínio, hoje, são cerca de 900 mil3. A posse e o usufruto da terra se faziam na medida das necessidades das tribos, com respeito religioso à "mãe terra".

Os invasores, considerando-a "terra de ninguém”, tornaram-na propriedade da coroa portuguesa, com o direito de explorá-la ao bel prazer. Os indígenas foram expropriados de seu direito fundamental de posse da terra e, no desenrolar desse atropelo, teve início o processo de devastação da natureza, que a consciência atual considera sujeito de direitos.

A partir de 1500 as terras brasileiras passaram ao domínio público do Reino de Portugal de modo que, quando começa a colonização portuguesa no Brasil com a constituição das capitanias hereditárias e as concessões de Sesmarias, inicia-se o processo de formação da propriedade privada no Brasil (ALCÂNTARA Fo; FONTES, 2009, p. 64-65).

\footnotetext{
${ }^{2}$ Segundo Azevedo (2000), "alguns autores estimam a população indígena no século XVI entre 2 e 4 milhões de pessoas, pertencentes a mais de 1.000 povos diferentes".

3 "Os mais de 240 povos indígenas somam, segundo o Censo IBGE 2010, 896.917 pessoas. Destes, 324.834 vivem em cidades e 572.083 em áreas rurais, o que corresponde aproximadamente a 0,47\% da população total do país" (Instituto Socioambiental, s.d.).
}

Horizonte, Belo Horizonte, v. 15, n. 47, p. 797-827, jul./set. 2017 - ISSN 2175-5841 
Os portugueses, desde o início, consideraram o Brasil como "mina" inesgotável de matéria prima. "O objetivo deles não era estabelecer uma colônia de colonização e sim uma colônia de exploração de nossa gente e de nossas riquezas” (Zen, 2005, p. 210 - grifo nosso).

As capitanias hereditárias, criadas em 1534 pelo rei de Portugal, consistiram em dividir as terras brasileiras em grandes faixas e confiá-las a indivíduos bem relacionados com a corte portuguesa. Os novos proprietários, “donatários”, tinham direito à posse da terra, não à propriedade, que era da Coroa Portuguesa. Além de "proteger" a terra contra invasões inimigas, deveriam colonizá-la e explorar os recursos naturais. O sistema, tendo funcionado mais de dois séculos, foi supresso em 1759.

O regime de sesmarias conviveu com as capitanias hereditárias. Os 12 donatários, incapazes de cultivar suas imensas extensões de terra, permitiam aos colonos, sesmeiros, cultivar porções de terra improdutivas. Embora não sendo proprietários, tinham o direito de permitir que outros trabalhassem suas terras. Os sesmeiros, por sua vez, sublocavam as terras a pequenos agricultores, que se tornavam posseiros. Uma prática ilegal consistia em pagar para se apoderar da terra.

A concessão de novas sesmarias foi encerrada em 1822, ano da Independência do Brasil. A violência no campo agravou-se! Bandos armados estavam a serviço dos proprietários e de quem se apoderava de terra alheia. Os trabalhadores na terra, muitos ex-escravos, foram vítimas dos conflitos, nesse período de vácuo jurídico.

Esses quase trinta anos entre a derrubada do regime sesmarial e a instituição de uma nova Lei ficaram conhecidos como 'Império de posses' ou 'fase áurea do posseiro', pois não havendo nenhum tipo de normatização e regulamentação de terras, a posse tornou-se a única forma de aquisição de terras (ALCÂNTARA Fo; FONTES, 2009, p. 66). 
A Lei de Terras (1850) iniciou nova fase da questão fundiária brasileira, num tempo de plena expansão do capitalismo. A terra fazia parte desse cenário, pela capacidade produtiva a ser explorada em vista do consumo e do lucro. A Lei de Terras normatizou os direitos e os deveres em relação à propriedade da terra, para ordenar a ação de sesmeiros e posseiros. O fim do tráfico de escravos, com a chamada Lei Áurea (13/05/1888), incentivou a imigração europeia para o Brasil com o objetivo de desenvolver a produção agrícola.

Os proprietários não poderiam mais obter sesmarias e as novas ocupações teriam reconhecimento legal. As terras sem proprietários e fora do controle do Estado, "terras devolutas", poderiam ser adquiridas do governo. Proibiu-se a ocupação de terras públicas. Isso permitiu aos imigrantes terem acesso à terra, embora com grandes restrições para chegarem a ser pequenos e médios proprietários. Entretanto, a lei favoreceu aos latifundiários ampliarem suas propriedades, em detrimento dos pequenos proprietários. Muitos imigrantes e exescravos se tornaram seus assalariados.

A injustiça no campo passou a ter respaldo legal por meio de documentos forjados nos cartórios de registro de imóveis. Os grandes proprietários ampliavam, sempre mais, seus domínios, donde muitos dos atuais latifúndios, recorrendo à violência e ao assassinato.

A Lei de Terras teve, pois, dois desdobramentos perversos: respaldou os latifúndios antigos e permitiu a formação de novos; transformou a terra em objeto de compra e venda. As "cercas" dos imensos latifúndios simbolizavam um país marcado pela injustiça no campo. "Para o MST, o ato de ocupar a terra - que eles chamam de 'cortar o arame' - é a pedra de toque do movimento. É o batismo de fato para o militante, uma parte essencial da sua identidade" (BANDFORD; ROCHA, 2004, p. 99). 
A Proclamação da República (15/11/1889) não modificou o cenário fundiário brasileiro. Os latifundiários continuaram detentores do poder político. Os “coronéis", personagens violentos e prepotentes, tornaram-se verdadeiros "donos” dos Estados, onde imperavam acima de qualquer lei.

Durante o regime militar (1964-1985), tiveram origem as primeiras iniciativas em vista da reforma agrária no Brasil, com a promulgação do Estatuto da Terra (1964), a criação do Instituo Nacional de Desenvolvimento AgrárioINDA (1964) e o Instituto Brasileiro de Reforma Agrária-IBRA (1969). O primeiro Plano Nacional de Reforma Agrária (1966) não chegou a ser implementado. Em 1970, foi criado o Instituto Nacional de Colonização e Reforma Agrária-INCRA, como junção do IBRA e do INDA, que serviu à política dos ditadores e suas obras faraônicas. Uma delas foi a rodovia transamazônica, cujas margens foram ocupadas por migrantes de muitos Estados brasileiros. Os latifundiários foram beneficiados com incentivos fiscais para desenvolver grandes projetos agrícolas e tornar a região numa das maiores produtoras de grãos, em detrimento da agricultura de subsistência dos pequenos agricultores.

Com a volta da democracia, foi promulgado um novo Plano Nacional de Reforma Agrária (1985) e criado o Ministério Extraordinário para o Desenvolvimento e a Reforma Agrária-MIRAD. Em 1989, a reforma agrária passou para a responsabilidade do Ministério da Agricultura, com a extinção do INCRA e do MIRAD. Posteriormente, o INCRA foi recriado e a reforma agrária ligada, diretamente, à Presidência da República, através do Ministério Extraordinário de Política Fundiária (1996). Em 1999, foi criado o Ministério do Desenvolvimento Agrário-MDA, do qual o INCRA passou a depender. Foram-lhe atribuídas diversas tarefas: promover a reforma agrária e reordenar a propriedade da terra, regularizar a posse da terra na Amazônia Legal, promover a agricultura familiar, demarcar as terras que foram ocupadas pelos descendentes das comunidades dos quilombolas. À Fundação Nacional do Índio (1967) caberia cuidar da delimitação das terras indígenas, cobiçadas pelos latifundiários. 
Sem a pressão das bases, a realidade fundiária brasileira jamais se modificará, sendo inútil a ação de governantes e políticos. A luta popular pela posse da terra, ao longo de séculos, visa a tão sonhada verdadeira reforma agrária, pois, “somente através de um programa estruturado de Reforma Agrária, de caráter abrangente e com vistas ao desenvolvimento econômico seria possível mudar a realidade atual" (ALCÂNTARA Fo; FONTES, 2009, p. 83).

\section{Luta pela terra - uma longa história}

O Movimento dos Trabalhadores Rurais Sem Terra (MST) é a expressão atual da luta secular pela posse da terra, constituindo-se num "dos mais importantes movimentos sociais de toda a história do Brasil” (FERNANDES, 2000, p. 14). Esse longo processo histórico caracteriza-se tanto como luta pelos Direitos Humanos, quanto pelos Direitos da Natureza.

Não há como desassociar o fenômeno da concentração de terras no Brasil com a forma de ocupação do território pelo colonizador europeu: inicialmente a ocupação das terras indígenas; posteriormente a lavoura de exportação - a monocultura tocada a braço escravo. Atualmente, a produção em larga escala, conhecida como agronegócio. Assim, podemos concluir que a luta de resistência à dominação começou com a chegada dos colonizadores no Brasil (LAUREANO, 2007, p. 39-40).

Os primeiros a lutar pela posse da terra foram os indígenas brasileiros4. Com a invasão portuguesa, foram privados da liberdade e da terra, escravizados e massacrados, num verdadeiro genocídio.

Dentre as lutas indígenas de resistência à escravização e à tomada de suas terras, estão: a Confederação dos Tamoios (1556-1567), no litoral de São Paulo e do Rio de Janeiro, a Guerra dos Potiguaras (1586-1599), no Rio Grande do Norte e as

\footnotetext{
${ }^{4}$ Para Thomaz Júnior (2010, p. 5), “É fundamental distinguir a luta pela terra da luta pela reforma agrária. Primeiro, porque a luta pela terra sempre aconteceu, com ou sem projetos de reforma agrária. Segundo, porque a luta pela terra é feita pelos trabalhadores e da luta pela reforma agrária participam, além dos trabalhadores, diferentes instituições (Estado, partidos políticos, movimentos sociais, ONGs etc.)".
}

Horizonte, Belo Horizonte, v. 15, n. 47, p. 797-827, jul./set. 2017 - ISSN 2175-5841 
reduções jesuíticas (séc. XVI-XVIII), no sul do Brasil, fronteira com a Argentina, Paraguai e Uruguai.

Com a recusa dos indígenas de se submeterem aos caprichos dos portugueses, preferindo a morte, teve início o tráfico de africanos para o trabalho escravo, nas mais variadas atividades, dos engenhos de açúcar às casas de seus donos.

Os negros africanos, também, se rebelaram, movidos pelo ideal da posse da terra, livres dos opressores. O principal movimento de resistência foi o Quilombo dos Palmares, na então Capitania de Pernambuco (atualmente, Alagoas), cujo líder mais conhecido foi Zumbi. Por volta de 1597, já haviam se reunido "negros, alguns índios e também trabalhadores livres e marginalizados pela sociedade colonial” (FERNANDES, 2000, p. 26), para viverem longe da escravidão portuguesa. Em 1695, o quilombo foi definitivamente arrasado e os quilombolas, aniquilados.

Embora o quilombo de Palmares tenha sido o mais conhecido,

muitos foram os quilombos criados em diferentes porções do território. Desde o Pará até o Rio Grande do Sul, passando pelo Maranhão, Piauí, Ceará, Paraíba, Pernambuco, Alagoas, Sergipe, Bahia, Minas Gerais, Rio de Janeiro, Goiás, Mato Grosso, São Paulo, Paraná e Santa Catarina. Foram três séculos de revoltas que conduziram ao enfrentamento contra o insustentável sistema escravocrata (FERNANDES, 2000, p. 26).

Uma luta histórica pela posse da terra aconteceu no sertão da Bahia. Liderado por Antônio Conselheiro, em 1893, um grupo de camponeses e exescravos instalou-se numa fazenda conhecida como Canudos, depois chamada de Belo Monte, e, aí, começou a desenvolver um estilo de vida alternativo ao latifúndio.

A organização econômica se realizava por meio do trabalho cooperado, o que foi essencial para a reprodução da comunidade. Todos tinham direito à terra e desenvolviam a produção familiar, garantindo um fundo comum para uma parcela da população, especialmente os velhos e desvalidos, que não tinham como subsistir dignamente (FERNANDES, 2000, p. 29).

Horizonte, Belo Horizonte, v. 15, n. 47, p. 797-827, jul./set. 2017 - ISSN 2175-5841 
O projeto de Antônio Conselheiro foi considerado uma afronta ao regime, resultando na declaração de guerra ao movimento. A Guerra de Canudos configurou-se com resistência camponesa ao sistema fundiário. Em 1897, o grupo foi violentamente exterminado, pois enfrentou os cinco mil soldados, armados para combater uma comunidade indefesa, mas, consciente de seus direitos e de sua dignidade.

Um movimento de caráter messiânico, liderado pelo "monge" José Maria, aconteceu no início do séc. XX, numa região litigiosa (contestada!) entre o Paraná e Santa Catarina. Foi esmagado na chamada Guerra do Contestado. Em 1912, oito mil trabalhadores, desempregados com o término da construção da ferrovia São Paulo-Rio Grande, desesperados pela situação, instalaram-se naquela região. Em 1914, acusados de pró-monarquia, foram atacados pelas tropas federais; "encurralados e sem suprimentos começava o fim da resistência" (FERNANDES, 2000, p. 31).

No início do séc. XX, originou-se uma forma de banditismo social, reação à desigualdade social no nordeste brasileiro, em especial, no tocante à posse da terra, conhecido como movimento do cangaço. "Os grupos eram formados, principalmente, por camponeses em luta pela terra, expulsos de suas terras pelos coronéis" (FERNANDES, 2000, p. 32). O cangaceiro mais famoso, Lampião, Virgolino Ferreira da Silva, atacava a todos sem distinção. Com ações violentas, assaltava fazendas e vilas, sequestrava latifundiários - "coronéis" -, saqueava armazéns e tropas de burros. Com sua morte, em 1938, e a intervenção do Governo Federal, o cangaço entrou em decadência, até desaparecer.

Ainda no nordeste, em 1946, surgiram as Ligas Camponesas, movimento de luta pela reforma agrária, tendo-se difundido em, pelo menos, 13 Estados. "As Ligas foram uma forma de organização política de camponeses proprietários, parceiros, posseiros e meeiros que resistiam à expropriação, à expulsão da terra e ao assalariamento" (FERNANDES, 2000, p. 33). 
Seu principal líder, a partir de 1954, foi o advogado e deputado Francisco Julião, afiliado ao Partido Socialista Brasileiro, embora a formação das Ligas tenha acontecido pela ação de base do Partido Comunista Brasileiro. Os trabalhadores rurais lutavam por seus direitos e postulavam uma revolução no cenário fundiário. Por ocasião do golpe militar de 1964, muitos integrantes das Ligas foram aprisionados ou assassinados.

Uma liderança importantíssima do MST, João Pedro Stedile, declara: "Nós do MST nos consideramos herdeiros e seguidores das Ligas Camponesas, porque aprendemos com sua experiência histórica e ressurgimos com outras formas" (STEDILE; FERNANDES, 1996, p. 18).

Um capítulo importante nessa luta foi escrito pelos sindicatos de trabalhadores rurais, ao longo do século passado, culminado com a fundação da Confederação Nacional dos Trabalhadores na Agricultura - CONTAG, em 1963. O contexto político era tenso, na cidade e no campo, culminando com o dramático golpe militar e a ditatura que implantou (1964-1985) com a consequente perseguição, prisão e assassinato dos líderes camponeses.

Todo o processo de formação das organizações dos trabalhadores foi destruído. Igualmente significou a impossibilidade dos camponeses ocuparem seu espaço político, para promoverem seus direitos [...] No campo, o avanço do capitalismo fez aumentar a miséria, a acumulação e a concentração da riqueza. [...] Também expropriou e expulsou da terra os trabalhadores rurais, causando o crescimento do trabalho assalariado e produzindo um novo personagem da luta pela terra e na luta pela reforma agrária: o boia-fria (FERNANDES, 2000, p. 41).

Nesse contexto, foi gestado o MST para fazer frente ao latifúndio que imperava, em detrimento dos pequenos agricultores e dos dependentes da terra para sobreviver.

O MST é um movimento que representa a luta de agricultores acostumados com o trabalho familiar e que resolveram lutar pela terra. Pessoas que descobriram na luta e aprenderam a acreditar, e assim passam a defender que a terra é de quem nela trabalha. Lutam contra o monopólio da terra em mãos de poucos - os latifundiários. Para o MST, o

Horizonte, Belo Horizonte, v. 15, n. 47, p. 797-827, jul./set. 2017 - ISSN 2175-5841 
latifúndio representa toda forma de exclusão: política, social e econômica da maioria da população (LAUREANO, 2007, p. 83).

\section{Reforma agrária: um ideal frustrado pelo latifúndio}

A atual política econômica privilegia o agrobusiness em detrimento dos pequenos agricultores e da agricultura familiar. Enormes investimentos governamentais favorecem a concentração de terras por um grupo reduzido de latifundiários e de empresas nacionais e estrangeiras, com o risco de eliminar o campesinato5. Resultado dessa política é o crescimento dos aglomerados de favelas, ambiente favorável para a proliferação de mazelas sociais.

Um fenômeno fundiário importante refere-se à migração de descendentes dos primeiros imigrantes europeus e asiáticos, do sul para o centro-oeste e norte do Brasil, em busca de terra de cultivo. Diferentemente dos antepassados, chegados ao Brasil, fugindo da fome e da pobreza, têm mentalidade latifundista e colonizadora, sem respeito aos ocupantes das terras das quais se apropriam.

A guerra no campo pela posse da terra tem sido sangrenta. Os latifundiários são bem organizados política e militarmente. Partidos políticos os defendem, impedindo a implantação de projetos agrários de interesse popular. Seus capangas e capatazes estão bem armados. O número de mortes no campo configura como guerra civil o conflito entre latifundiários e pequenos agricultores.

A ação das Igrejas, solidárias com as vítimas do latifúndio, é um tópico dessa história. A Igreja profética é abertamente rechaçada com acusações e calúnias e assassinato dos líderes mais combativos. Contudo, existem padres e pastores alinhados com os latifundiários, pelas "ajudas generosas", que lhes fecham os olhos.

\footnotetext{
${ }^{5}$ Segundo Antonio Thomaz Júnior (2010, p.22), "as mudanças na questão agrária, na primeira década do século XXI, revelam que os movimentos sociais camponeses passaram a se confrontar cada vez mais com corporações transnacionais e cada vez menos com latifúndios, cada vez mais com o capital nacional, consorciado a diversos interesses do capital transnacional, desde o processo agroindustrial, construção de barragens etc."
}

Horizonte, Belo Horizonte, v. 15, n. 47, p. 797-827, jul./set. 2017 - ISSN 2175-5841 
A Igreja Católica desempenhou um papel importante na luta pela terra no Brasil, a partir de Medellin (1968), com o surgimento das Comunidades Eclesiais de Base (CEBs) e da Teologia da Libertação ${ }^{6}$. A questão agrária foi relacionada com o tema da fé e a posse da terra tornou-se questão de fidelidade ao Evangelho, impedindo os agricultores cristãos de se acomodarem.

Para a Igreja Católica,

é imperativo ético, espiritual, social, econômico e ambiental a luta pela posse da terra e seus bens naturais como forma de erradicar a pobreza. [...] Toda e qualquer propriedade mantida como fonte de especulação, de exploração e de poder não é legitima. [...] Por essa razão, reafirmamos que é nossa obrigação moral fazer tudo o que estiver ao nosso alcance para que o latifúndio tenha limites (CNBB, 2014, p. 85)7.

Em 1975, foi criada a Comissão Pastoral da Terra (CPT), braço da Igreja Católica para acompanhar e apoiar as lutas dos camponeses (cf. CPT, 1983) ${ }^{8}$. Seu lugar de origem foram as paróquias dos interiores e das periferias e as CEBs rurais. A CPT tomou corpo e suas denúncias se fizeram ouvir nos meios de comunicação. Vários bispos profetas tiveram seus nomes ligados à CPT e se fizeram conhecidos pela oposição decidida ao latifúndio 9 .

Apesar dos esforços, "a distribuição de terras no Brasil permanece estabilizada em altos patamares de desigualdade, de modo que as políticas agrárias e fundiárias não têm sido eficientes no sentido de modificar a estrutura fundiária brasileira, pelo menos no que se refere ao curto prazo" (ALCÂNTARA Fo; FONTES, 2009, p. 64).

\footnotetext{
6 “O MST iniciou-se como um movimento vinculado à Igreja Católica, apoiado pelas alas da Teologia da Libertação, ecumênica, e ainda utiliza diversas atividades místicas em suas atividades, inclusive em seu projeto educativo, pois, em diversas atividades de formação de professores ou nas escolas de assentamentos, a mística aparece com muita frequência e força, apesar do caráter político laico nas atividades atuais" (MENEZES NETO, 2012, p. 97). "O MST surge do trabalho das Igrejas Católica e Luterana. Esse trabalho pastoral das igrejas também faz parte da gênese do MST" (STEDILE; FERNANDES, 1996, p. 18-19).

7 “O crescimento das igrejas neopentecostais e da igreja carismática católica, nos assentamentos, apresenta-se como um fator de perda de influência da Teologia da Libertação" (MENEZES NETO, 2012, p. 76).

${ }^{8}$ A influência da CPT na formação do MST foi estudada por Pinto (2015, p. 76-88).

9 "A CPT foi a aplicação da Teologia da Libertação na prática, o que trouxe uma contribuição importante para a luta dos camponeses pelo prisma ideológico. Os padres, agentes pastorais, religiosos e pastores discutiam com os camponeses a necessidade de eles se organizarem. [...] A CPT fez um trabalho muito importante de conscientização dos camponeses" (STEDILE; FERNANDES, 1996, p. 20).
}

Horizonte, Belo Horizonte, v. 15, n. 47, p. 797-827, jul./set. 2017 - ISSN 2175-5841 
Para Rocha e Cabral,

Conflitos entre os latifundiários e os trabalhadores sem terra na disputa pela terra, resultam no antagonismo entre essas classes sociais onde o interesse pela terra consiste em objetivos distintos, os latifundiários não querem abrir mão da terra por interesses capitalistas, enquanto o trabalhador sem terra luta pela chance de ter um pedaço de chão para se fixar com sua família e a partir daí conquistar melhores condições de vida (ROCHA; CABRAL, 2016, p. 85).

\section{O MST: os camponeses sem terra em busca de seus direitos}

O MST surge no bojo de uma luta secular pela terra, para garantir um Direito Humano básico e, concomitantemente, pôr-se em defesa dos Direitos da Natureza. Para um líder do movimento, "o MST é a continuidade de um processo histórico de lutas populares. Esperamos ser um elo com as lutas futuras. Este é o nosso papel histórico" (LAUREANO, 2007, p. 34).

É mais uma tentativa de minar, pelas bases, o latifúndio no Brasil e criar justiça social ao campo. Como movimento popular contemporâneo,

o MST, ao lutar pela democratização da terra e, nela, pelos direitos de cidadania, fundamenta novos valores, em que resgata: a relação entre campo e cidade; a relação entre teoria e prática; a cultura popular e a identidade dos sujeitos do campo; o conceito de terra como condição essencial para o efetivo exercício dos direitos de cidadania, como o trabalho, a moradia, a solidariedade, em que o indivíduo já não está lançado à própria sorte, sem rumo nem direção, mas se sente participante de uma coletividade que, ao lavrar a terra, lavra a vida, recuperando desta forma a dignidade e a humanidade que nos foi roubada pelo sistema capitalista" (ZEN, 2005, p. 222-221).

Em sua obra A formação do MST no Brasil, Fernandes (2000) segmenta a história do movimento em três grandes períodos: gestação e nascimento (19791985), territorialização e consolidação (1985-1990), territorialização e institucionalização (1990-1999).

4.1 O movimento começa a tomar corpo em 1979, em Ronda Alta-RS, quando o pároco da cidade, militante da CPT, acolheu um grupo de sem-terra em

Horizonte, Belo Horizonte, v. 15, n. 47, p. 797-827, jul./set. 2017 - ISSN 2175-5841 
busca de um lugar para se estabelecer. Refletindo sobre o êxodo bíblico, decidiu-se pela organização para lutar por seus direitos, para além da preocupação de criar novo acampamento. Uma grande mobilização reuniu "em torno de 1.100 famílias” que "deliberaram que as soluções para os seus problemas deveriam ser alcançadas em comum e não de forma individualizada”, e, mais, encaminhariam um abaixoassinado ao governador do Estado, reivindicando serem assentados, caso contrário, ocupariam novamente outra área de onde haviam sido expulsos (FERNANDES, 2000, p. 52). Sem resposta das autoridades, decidiram ocupar a Gleba Macali, na madrugada de 7 de setembro de 1979, data simbólica por ser festa da Independência do Brasil. Daí a decisão de fincar uma cruz no lugar e "na cruz colocaram a bandeira do Brasil, porque era o dia da pátria e porque lutavam para serem cidadãos" (FERNANDES, 2000, p. 53). Era como se revivessem o êxodo de Israel, como recordava a leitura bíblica proclamada na celebração que fizeram.

A repressão não tardou. Entretanto, a resistência dos acampados impediu o sucesso da ação policial. O governo voltou atrás, as famílias se instalaram e começaram o cultivo da terra. Foi o início de um movimento social que se espalharia pelo território nacional.

A fundação oficial do MST aconteceu no Encontro Nacional dos Sem Terra, em Cascavel-PR, em janeiro de 1984, com os seguintes objetivos:

1 - lutar pela reforma agrária; 2 - lutar por uma sociedade justa, fraterna e acabar com o capitalismo; 3 - integrar à categoria dos semterra: trabalhadores rurais, arrendatários, meeiros, pequenos proprietários etc.; 4 - a terra para quem nela trabalha e dela precisa para viver (FERNANDES, 2000, p. 52 - grifo do autor).

4.2 Com a multiplicação de encontros e congressos, em vários Estados, o MST se consolidou, com a criação de uma estrutura básica.

Essa estrutura, formada pela coordenação, direção, secretaria e setores, foi concebida desde as práticas das organizações camponesas históricas e, principalmente, das experiências vivenciadas, quando as famílias organizaram comissões e núcleos nos acampamentos e nos assentamentos. [...] Desse modo, os sem-terra criaram suas instâncias de 
representação que são a direção e a coordenação estaduais, as coordenações de assentamentos e acampamentos (FERNANDES, 2000, p. 95).

4.3 Quanto mais pessoas aderiam ao MST, tanto mais necessidade havia de articular as lideranças, desde a cúpula até os níveis mais baixos. Gestou-se, então, um programa em torno da ocupação das terras improdutivas, da infraestrutura dos assentamentos e ocupações, da educação para os filhos dos assentados, de adolescentes e de adultos, da comercialização dos produtos e do financiamento da produção ${ }^{10}$. Em nível macro, estava o desafio de manter a unidade do movimento, para não se tornar pequenos núcleos desconectados.

Criar uma organização autônoma, socializar os conhecimentos dos direitos, romper o isolamento e ampliar as lutas e o Movimento são condições fundamentais para a construção da forma de organização do MST. Foram esses os objetivos que os sem-terra carregaram, quando partiram para construir novos espaços de lutas pelo território nacional. [...] A reflexão sobre as experiências de luta e enfrentamento gerou uma metodologia de luta popular. [...] Esse aprendizado possibilitou a rápida territorialização do MST pelas regiões brasileiras (FERNANDES, 2000, p. 96).

A dinâmica de organização acontecia, simultaneamente, em vários Estados, causando inquietação nas elites urbanas e nos latifundiários, pois a ocupação tornou-se a marca do MST.

4.4 Evento importante foi o $2^{0}$ Congresso do MST, em 1990, com suas instâncias de organização e articulação bastante consolidadas e em fase de ampliação. Nesse ano, ocorreu um evento de larga repercussão: a primeira ocupação no Pontal do Paranapanema-SP (cf. FERNANDES, 2000, p. 199). E teve início uma fase difícil: os dois anos e meio do governo Collor (1990-1992). "Nesse tempo, ocorreu uma escalada de repressão contra o Movimento, de modo que,

\footnotetext{
10 "O MST nunca se descuidou dos processos de formação da sua base, pelo contrário, conseguiu estabelecer uma referência na área da formação, no campo da esquerda brasileira" (OLIVEIRA, 2014, p. 88). Para uma liderança destacada do MST, "nunca terá futuro a organização social que não formar os seus próprios quadros. [...] Precisamos de quadros técnicos, políticos, organizadores, profissionais de todas as áreas" (STEDILE; FERNANDES, 1996, p. 42-43).
}

Horizonte, Belo Horizonte, v. 15, n. 47, p. 797-827, jul./set. 2017 - ISSN 2175-5841 
considerando a palavra de ordem ocupar, resistir, produzir, o resistir foi mais intensificado" (FERNANDES, 2000, p. 199 - grifo do autor).

Tendo se voltado para dentro, o processo de institucionalização avançou com duas iniciativas: o Sistema Cooperativista dos Assentados e a Confederação das Cooperativas de Reforma Agrária do Brasil - CONCRAB (FERNANDES, 200o, p. 200).

As elites e os latifundiários não cessam de demonizar um "dos mais importantes movimentos sociais de toda a história do Brasil" (FERNANDES, 2000, p. 14) e tudo fazem para dificultar-lhe a ação. Porém,

muitas são as ações que o MST realizou em prol dos brasileiros, como a criação de oportunidades de trabalho e renda e das condições efetivas para que milhares de crianças, jovens e adultos tivessem acesso à educação em acampamentos e assentamentos. [...] Todavia, a maior conquista foi transformar pessoas sem-rosto em cidadãos (LAUREANO, 2007, p. 31 grifo nosso).

A educação de crianças, jovens e adultos é uma questão de honra para o MST. Por isso, “onde quer que haja uma ocupação, acampamento ou assentamento do MST, há uma escola. [...] A luta pela terra se tornou, também, uma luta por educação, por escolas, pelo direito de saber" (BANDFORD; ROCHA, 2004, p. 157).

Uma convicção fundamental no âmbito do movimento é que "o MST deve lutar contra três cercas: a do latifúndio, a do capital e a da ignorância” (STEDILE; FERNANDES, 1996, p. 75).

O MST tem seu modo particular de entender a educação, focando na convicção de que "os Sem-Terra podem ser considerados um sujeito coletivo criativo e produtor de conhecimento" (MESQUITA; NASCIMENTO, 2014, p. 1081 - grifo dos autores). A pedagogia de Paulo Freire tornou-se referencial para a educação no âmbito do movimento. 
Outro fator importante é a largueza de horizonte e os objetivos prefixados pelo MST. Para além da implementação da ansiada reforma agrária,

o MST, ao ocupar terras, devolutas ou não, que não estejam cumprindo sua função social, está contribuindo para repensarmos a própria noção de território e de nacionalidade. [...] O MST, ao ocupar a terra enquanto parte do território que se encontra sob o domínio do latifúndio, neste caso a serviço da classe dominante, e não a serviço da nação (função social da terra), busca socializar a terra para que ela exerça seu papel social, que é o de produzir alimentos para o sustento do povo brasileiro (Zen, 2005, p. 215).

O MST está escrevendo uma história que passa da "cultura de resistência" para uma "cultura de libertação" (BANDFORD; ROCHA, 2004, p. 339), na qual os historicamente marginalizados conquistam o direito de cidadania ${ }^{11}$.

\section{A luta paradigmática pela terra: o povo da Bíblia}

A questão da terra é central na teologia de Israel: "A Bíblia é a narrativa do povo de Deus com a terra de Deus. [...] A experiência de Israel é de estar e pertencer a uma terra nunca plenamente dada, nunca totalmente segurada" (BRUEGGEMANN, 1986, p. 14.28).

No âmbito da Bíblia, "o direito de posse da terra e o privilégio de morar em seus confins eram considerados conceitos centrais para a vida e a fé de Israel. [...] A terra constituiu fato de importância capital para Israel, tanto do ponto de vista sociológico como teológico" (DAVIES, 1995, p. 348.350).

A fé de Israel alicerça-se na libertação do povo da terra da opressão e sua condução para a terra da fraternidade, obra da solidariedade divina, sem a qual estaria fadado a desaparecer. A narrativa bíblica descreve, com vivacidade, a preocupação de Deus com o Israel oprimido: "Eu vi, eu vi a miséria do meu povo

\footnotetext{
${ }^{11}$ Em meio a conquistas e reveses, num "guerra" diuturna contra o latifúndio, com assassinatos de seus líderes, o MST segue adiante na busca de alcançar o ideal da Reforma Agrária no Brasil, como se pode acompanhar em seu site www.mst.org.br, em suas publicações e na mídia (RODRIGUES, 2017; COSME, 2016).
}

Horizonte, Belo Horizonte, v. 15, n. 47, p. 797-827, jul./set. 2017 - ISSN 2175-5841 
que está no Egito. Ouvi seu grito por causa dos seus opressores; pois eu conheço as suas angústias. Por isso desci a fim de libertá-lo da mão dos egípcios, e para fazê-lo subir desta terra para uma terra boa e vasta, terra que mana leite e mel" (Ex 3,7$8)^{12}$.

De fato, "Essa terra grande e fértil [...] permanecerá sempre como uma espécie de meta a ser alcançada: um ponto de referência que é importantíssimo para a motivação e mística, que assumirá a luta” (CARAVIAS; BARROS, 1990, p. 48).

Moisés foi o grande líder dessa epopeia, como mediador histórico da ação divina. "Vai, pois, e eu te enviarei a faraó, para fazer sair do Egito o meu povo, os israelitas" (Ex 3,10).

O livro de Josué descreve a posse e a distribuição da terra entre as tribos egressas do Egito, fim de um período sombrio na vida do povo e perspectiva de vida nova, sob a égide da fraternidade. Tudo acontece por obra de Deus que concede a terra e dá repouso a seu povo (cf. Js 1,13.15; 21,44). A posse da terra é condição para o povo viver em paz, sem as tribulações de escravo, trabalhando em terra alheia. Assim, “para Israel a terra não é algo meramente material, uma simples mercadoria, mas um elemento religioso de seu ambiente vital: é um dom de Deus, é expressão da presença de Deus em sua vida, pois foi Javé quem deu esta terra (Jz 11,24)" (CODINA, 1995, p. 27).

$\mathrm{O}$ ideal de fraternidade frustrou-se pela ação dos reis de Israel. Distanciando-se do projeto original de Deus, foram promotores de injustiças, entre elas, a posse ilegítima da terra, tomada à força de indefesos cidadãos. Uma cena emblemática está narrada em 1Rs 21, o episódio da vinha de Nabot (cf. VITÓRIO, 2005, p. 82-95). Cobiçando a propriedade de um vizinho, o rei considera a terra objeto de troca e de comércio. Quanto a Nabot, a fé ancestral proibia-lhe abrir mão

\footnotetext{
12 "O conceito da terra como dom desenvolve-se mais no Deuteronômio. [...] Essa terra era o dom supremo que lahweh concederia a seu povo, e era dom que manifestamente transcendia toda expectativa humana" (DAVIES, 1995, p. 337).
}

Horizonte, Belo Horizonte, v. 15, n. 47, p. 797-827, jul./set. 2017 - ISSN 2175-5841 
da terra recebida em herança, mesmo com a possibilidade de possuir outra melhor. A posse da terra era uma espécie de sacramento de sua fé. Para ele, "a terra não é mercadoria negociável, mas sim herança inalienável” (BRUEGGEMANN, 1986, p. 134 - grifo do autor). Sua reação em face à proposta do rei reflete Lv 25,23: "As terras não se venderão a título definitivo, porque a terra é minha, e vós sois estrangeiros e meus agregados".

Essa visão contrastava com o modo de pensar cananeu, no qual "cada rei considerava-se o único dono da terra ao redor de seu reino. Acreditava-se que os deuses entregavam suas terras a seus 'filhos prediletos', que eram precisamente os reis. [...] As demais pessoas, menos estimadas pelos deuses, deveriam contentar-se com servir ao rei e aos seus" (CARAVIAS; BARROS, 1990, p. 46).

O episódio envolvendo Nabot corresponde a uma situação comum na Palestina do séc. VIII a.C. Os profetas foram duros em denunciar a mentalidade latifundista. Elias tomou as dores de Nabot e denunciou, sem meias palavras, a injustiça de Acab e sua esposa Jezabel (cf. 1Rs 21,17-26). Isaías proclamou: "Ai dos que juntam casa a casa, dos que acrescentam campo a campo até que não haja mais espaço disponível, até serem eles os únicos moradores da terra" (Is 5,8). Da mesma forma, Miqueias: "Ai daqueles que planejam iniquidade e tramam o mal em seus leitos! [...] Se cobiçam campos, eles os roubam, se casas, eles as tomam; oprimem o varão e sua casa, o homem e sua herança” (Mq 2,1-2). Joaquim, denunciado por Jeremias, representa o auge da maldade dos reis contra o povo indefeso. "Tu não tens olhos nem coração senão para o teu lucro, para derramar sangue inocente, para a opressão e para a violência” (Jr 22,17).

Mirando o futuro, Isaías antevê a ruína do sistema iníquo, onde a terra acumulada à custa de injustiça tornar-se-ia estéril, para frustração de quem dela se apossou por caminhos tortuosos. "Dez hectares de vinhedo de vinho só darão um barril. Dez medidas de semente de grão produzirão uma só!” (Is 5,9-10). Miqueias prospecta um futuro sombrio para os exploradores do povo, que se lamentarão: "Fomos completamente devastados, [...] nossos campos são partilhados em favor 
do infiel” (Mq 2,4). Para Isaías e Miqueias, o acúmulo da terra nas mãos de poucos contraria o querer divino; por isso, não subsistirá.

A preocupação da sabedoria bíblica pela questão da terra é explícita em Pr 22,28: "Não desloques os marcos antigos que os teus pais colocaram", em perfeita conexão com a lei, que ordenava: "Não removerás os marcos de teu próximo, que os antepassados fixaram na propriedade herdada na terra que o Senhor teu Deus te dá como posse” (Dt 19,14). Era muito fácil mover, em benefício próprio, as pedras que delimitavam as propriedades. Proibir tocá-las significava proteger os indefesos contra a ganância dos grandes. Tirar de seus lugares os "marcos antigos" era uma forma de pecado, por violar os limites de propriedade estabelecidos por Deus.

Pr 23,10-11 é ainda mais explícito: "Não desloques o marco antigo, e não entres no campo dos órfãos, pois o seu vingador é forte e disputará a causa deles contra ti”. Por não ter quem os defendesse, estavam sujeitos a perder a herança recebida de seus pais.

Na mesma linha, segue Pr 15,25: "Deus arranca a casa dos soberbos e finca os marcos do terreno da viúva”. Deus fica do lado da pobre desamparada, protegendo-a contra a ação dos ambiciosos, sem escrúpulos de expropriar as viúvas, com o risco de expô-las à escravidão (cf. 2Rs 4,1).

O exílio correspondeu à perda da terra e, por consequência, da liberdade, numa forma de volta ao "ponto zero" de uma longa história (BRUEGGEMANN, 1986, p. 21). Perder a terra significava perder a identidade religiosa; voltar seria um novo êxodo (cf. Is 40,3). Por isso, um grupo de israelitas fiéis nutria a esperança do retorno. Enquanto o profeta Jeremias anunciava um longo tempo de exílio (cf. Jr 29,4-10), os “falsos profetas" falavam de um exílio breve (cf. Jr 28,2-3).

A lei previa, a cada cinquenta anos, um jubileu (yobel), quando, quem perdera a terra, podia "retornar à sua propriedade e voltar para sua família" (Lv 25,10.13). O ano jubilar seria tempo de alegria, por permitir aos israelitas sem-terra 
superar uma situação anômala para a fé e recuperar a situação querida por Deus para seu povo ${ }^{13}$.

A terra parece não ser problema no Novo Testamento, no sentido veterotestamentário. A situação socioeconômica das primeiras comunidades cristãs era de extrema fragilidade. Sobreviver era um desafio! Para não haver necessitados entre eles, muitos "vendiam as propriedades e os bens e os distribuíam entre todos, conforme a necessidade de cada um" (At 2,45); "todos quantos eram proprietários de terrenos ou casas vendiam-nos, levavam o dinheiro e o depositavam aos pés dos apóstolos, para distribui-lo conforme a necessidade de cada um" (At 4,34-35). As comunidades deveriam se organizar, levando em consideração as carências dos irmãos e das irmãs (cf. At 6,1-7).

O desapego dos bens materiais foi um tema importante na pregação de Jesus de Nazaré. O discipulado do Reino exigia desfazer-se de tudo e partilhar com os pobres, como caminho de perfeição (cf. Mt 19,21). "Quem não renunciar a todas as suas posses, não poderá ser meu discípulo" (Lc 14,33). Daí se entende a decisão do rico Zaqueu de se desfazer da riqueza acumulada, ao se encontrar com Jesus (cf. Lc 19,1-10). A parábola do rico ganancioso ilustra a insensatez de acumular bens, sem a preocupação de partilhá-los (cf. Lc 12,16-21).

O discipulado cristão exige optar entre Deus e o dinheiro: "Não podeis servir a Deus e a Mamon” (Lc 16,13) e não "acumular tesouros na terra, onde a traça e o caruncho devoram e os ladrões invadem e roubam" (Mt 6,16). O discípulo do Reino vive uma fé inabalável na Providência, sem cair na tentação do materialismo (cf. Mt 6,25-34; Lc 12,22-31). E busca, em primeiro lugar, o Reino de Deus e sua justiça, pois tudo mais virá por acréscimo (cf. Mt 6,33).

A terra tem conotação nova na pregação de Jesus: é o destino dos discípulos missionários, com a missão de testemunhar o Reino “em Jerusalém, em toda a

\footnotetext{
13 “A propriedade dada como penhor não podia considerar-se como tendo sido 'alienada' no sentido estrito do termo, uma vez que o credor jamais podia se tornar proprietário, e o penhor sempre permanecia resgatável” (DAVIES, 1995, p. 346).
}

Horizonte, Belo Horizonte, v. 15, n. 47, p. 797-827, jul./set. 2017 - ISSN 2175-5841 
Judeia e na Samaria, até os confins da terra" (At 1,8). Ao declarar que os mansos são bem-aventurados e receberão a terra como herança (cf. Mt 5,5), o Mestre não pensa em propriedade fundiária. Possuirão a terra ao levar o anúncio do Evangelho até seus confins.

Paulo exorta a comunidade de Corinto a se comportar com liberdade em face às "coisas do mundo, usando-as como se não as usassem; pois a figura deste mundo passa” (1Cor 7,31). Em linguagem antropomórfica, alude à criação sofrendo dores de parto, "ansiando a liberdade gloriosa dos filhos de Deus" (Rm 8,19-23). O Apocalipse fala do surgimento de "um novo céu e uma nova terra; pois o primeiro céu e a primeira terra passaram"; aí, "não haverá mais morte, nem pranto, nem clamor, nem dor, porque as primeiras coisas passaram” (Ap 21,1.4). O tema da terra toma dimensões escatológicas e a terra física se torna secundária, na Carta a Diogneto (séc. II/III): "Qualquer terra estrangeira é uma pátria para eles (os cristãos) e toda pátria é terra estrangeira”.

Todavia, o tema da terra está inserido nas preocupações dos cristãos de todos os tempos, em especial, quem depende dela para sobreviver. A fé torna-os conscientes de seu direito inalienável à posse e usufruto da terra (cf. REIS, 2012, 94-109). Aceitar passivamente a expropriação, cruzar os braços e não lutar para conquistá-la ou esperar que lhe seja dada por iniciativa alheia são atitudes inexplicáveis dos discípulos e discípulas de Jesus de Nazaré, de nosso tempo.

\section{Deus em meio a conflitos: teologia da passagem de Deus, no passado e no presente, na luta pela terra}

A luta pela terra, tendo como referencial a experiência do povo bíblico, permite esboçar os elementos de uma teologia da passagem de Deus, cotejando o Israel de outrora e os agricultores em busca de terra para sobreviver ${ }^{14}$.

\footnotetext{
${ }^{14}$ No âmbito do MST, "a leitura bíblica feita com as ferramentas da hermenêutica popular ajuda a desmistificar as estruturas e suscita uma fé dinâmica, viva, engajada, livre, crítica, capaz de construir um sentido novo para a vivência pessoal, e a imaginar outro mundo possível, mais justo e humano. Evidentemente, há também o risco de leituras simplistas da Bíblia, que podem reafirmar medos, intolerâncias e certo sentimento sectário que antes de somar divide o movimento e a possibilidade de viver junto ecumenicamente" (ZWESTSCH, 2010, p. 91).
} 
6.1 O MST considera bênção o que a Bíblia apresenta como maldição. À expulsão de Adão e Eva do paraíso, segue-se a sentença divina: “Amaldiçoado será o solo por tua causa. Com sofrimento tirarás dele o sustento todos os dias de tua vida" (Gn 3,17). O sem-terra pensa o contrário: o solo é bendito e dele se tira o alimento com alegria. Essa postura coloca-o na condição anterior à maldição, quando o solo era abençoado e o que nele se produzia para o sustento humano.

A visão latifundista, sim, gera maldição. Na contramão, o MST tem como projeto recuperar a santidade original da terra, em sintonia com o desígnio do Criador. Trabalhar a terra significa co-criação. A ordem divina nas origens, "Dominai a terra" (Gn 2,28), assume um sentido positivo, incompatível com a tentação de destruí-la e degradá-la. A semântica de dominar exclui a ideia de assenhorear-se e poder usá-la sem preocupação com a sustentabilidade e a sobrevivência do Planeta. Antes comporta a ideia de cuidado e proteção.

Ao lutar pela posse da terra, valorizá-la e estabelecer com ela uma relação de respeito, por sua sacralidade, o MST coloca-se do lado do Criador e assume sua causa, como forma de reverter a maldição das origens.

6.2 A ideologia marxista é patente no modo de pensar e nas ações das lideranças do MST'15. Sua leitura da realidade inspira-se nela e dela tiram coordenadas para dirigir o movimento. Porém, essa não é a realidade de largas faixas das bases do movimento. O MST tem origens religiosas e as narrativas bíblicas do êxodo serviram-lhe de inspiração. Tanto a Igreja Católica quanto as Evangélicas são presenças importantes entre acampados e assentados ${ }^{16}$. A fé tem enorme importância na caminhada do MST, à revelia do ateísmo de seus líderes (cf. ZWESTSCH, 2010, p. 86-88).

\footnotetext{
${ }^{15}$ João Pedro Stedile afirma: “Fomos buscar nos pensadores clássicos de várias matrizes algo que pudesse contribuir com nossa luta. Lemos Lenin, Marx, Engels, Mao Tsé-Tung, Rosa Luxemburgo. De uma forma ou de outra, captamos alguma coisa de todos eles [...]. $O$ próprio Evangelho, não como uma religião mas como uma doutrina, também tem uma influência sobre nossos valores, nossa cultura, na forma de ver a mística, na forma de ver diferente" (STEDILE; FERNANDES, 1996, p. 59-60).

${ }^{16}$ João Pedro Stedile reconhece: "Como é que nós, que somos de esquerda, vamos sempre à missa? Para nós, não existe contradição nenhuma nisso. Ao contrário: a nossa base usa a fé religiosa que tem para alimentar a sua luta, que é uma luta de esquerda, que é uma luta contra o Estado e contra o capital" (STEDILE; FERNANDES, 1996, p. 131).
}

Horizonte, Belo Horizonte, v. 15, n. 47, p. 797-827, jul./set. 2017 - ISSN 2175-5841 
Não é equivocado afirmar que o sucesso do marxismo se deve, em larga escala, por sua formatação "religiosa", com seus dogmas, pecados, código de ética, liturgias, narrativas inspiradoras (=mitos fundantes?), bem como, suas recompensas e punições, no esquema da teologia da retribuição ${ }^{17}$. Isto poderia ser um facilitador da compreensão e da assimilação da proposta do MST, abraçada com seriedade e responsabilidade, próprias do fervor religioso.

A certeza da vitória - a conquista da terra -, cultivada no coração dos semterra é motivada pela convicção da guia divina e da luta de Deus em favor de seu povo, nos moldes da libertação da escravidão egípcia e da caminhada para a Terra Prometida (cf. MEINCKE, 1988). A ideologia marxista dos líderes convive com a fé dos acampados e dos assentados sem maiores problemas ${ }^{18}$.

6.3 A fé dos pobres e dos pequenos, na luta pela terra, está na origem da resistência e da perseverança nos conflitos com os latifundiários. O Deus da fé dá força para combater o ídolo do capital, cuja voracidade é ilimitada. Portanto, na ação do MST, se vislumbra a luta pela desidolatrização da sociedade, pela teimosia em se crer no Deus da vida e da libertação. Os sucessivos assassinatos de sem-terra podem ser considerados verdadeiros martírios na luta para recolocar a história nos trilhos queridos pelo Deus criador e libertador.

Assim, seria equivocado limitar a análise do MST aos componentes sóciopolítico-econômicos. Algo profundamente religioso subjaz aos ideais cultivados pelo movimento ${ }^{19}$. Quiçá, o elemento religioso funcione como agente agregador dos múltiplos componentes da vida e da ação dos sem-terra. Quem reconhecer o fator

\footnotetext{
${ }^{17}$ Para Berdiaev, a apocalíptica e o milenarismo explicam "o sentido religioso do comunismo russo, que seria uma espécie de messianismo apocalíptico secular e ateu, porém possuindo os mesmos traços do messianismo religioso: dogmatismo, absolutismo, misticismo, dimensão totalizante, espírito missionário e nacionalista" (CODINA, 1997, p. 159).

${ }^{18}$ No pensar de uma liderança do MST, "a Teologia da Libertação tem uma origem marxista, tem umas ideias marxistas. Então, o Movimento tem essa parte mais de fé mesmo que vem da teologia, de acreditar e de fazer um Deus vivo, e tem a parte marxista mesmo. Eu acho que o Movimento conciliou isso aí e é vivo até hoje por causa disso"; embora haja quem pense na direção oposta: "Já nos desligamos da Igreja e nós não somos uma igreja. Nós queremos o MST livre dessas doutrinas. Nós não queremos forjar um ser doutrinado. A gente quer trabalhar com trabalhador que tenha autonomia, que tenha as suas próprias ideias e não a ideia de um Deus" (MENEZES NETO, 2012, p. 105).

${ }^{19}$ Segundo Antonio Alves de Almeida, "A cruz está presente sob diversas formas [no MST]: em desenhos, confeccionada em madeira, com um desenho do trabalhador sobre a mesma, utiliza-se terra umedecida com água para fazer o sinal da cruz na testa de todos os presentes, assim ratifica-se a aliança de Deus com os seus filhos na conquista da terra" (ALMEIDA, 2005, p. 29).
}

Horizonte, Belo Horizonte, v. 15, n. 47, p. 797-827, jul./set. 2017 - ISSN 2175-5841 
ideológico como elemento unificador, haverá de considerar seu substrato religioso, sem o qual os mais carentes de terra, jamais adeririam ao $\mathrm{MST}^{20}$.

6.3 As narrativas bíblicas da libertação egípcia dão enorme ênfase à guia de Moisés. Por ordem divina, o líder fala ao faraó em nome do povo; orienta a preparação para a fuga; caminha à frente na travessia do mar e na longa marcha pelo deserto. O grande desafio consistiu em se fazer ouvir e levar o povo a seguir suas ordens. A Bíblia alude às contínuas murmurações, causa de irritação para Moisés. A união do povo era um ideal desejado, mas não totalmente alcançado.

A luta pela terra no Brasil, ao longo dos séculos, e, recentemente, no MST, retoma os passos do Israel bíblico. Moisés encarna-se na ação dos líderes das lutas pela conquista da terra, enfrentando as forças poderosas dos latifundiários armados para impedir o movimento de libertação de indefesos agricultores. Sem a ação dos líderes, seria impossível imaginar o êxito da luta pela terra. São muitos os “Moisés” brasileiros!

O ideal da união do povo deve ser acalentado pelo MST, em meio a muitas divisões, conflitos internos, murmurações, egoísmos, rebeldias, autoritarismo e, até, mortes. Determinante é o foco mantido no objetivo de conquistar e usufruir a terra.

6.4 Um elemento teológico importante no MST é a sacralidade da terra, que é de todos e não pode ser acumulada nas mãos de alguns, impedindo o acesso a quem dela necessita para trabalhar e sobreviver. Resgata-se, assim, o sentido bíblico da terra, centrado no bem do ser humano, ao contrário da voracidade de lucro do agrobusiness. Milhões de toneladas de grãos são destinadas ao comércio exterior, olvidando a fome do povo. O Brasil é um dos maiores produtores de grãos do mundo, embora a fome seja uma vergonha nacional.

\footnotetext{
${ }^{20}$ Zwetsch destaca "três categorias bíblico-teológicas" presentes na caminhada de fé dos assentados e de sua liderança religiosa: a cruz, o batismo e a Bíblia (ZWESTSCH, 2010, p. 90-91).
}

Horizonte, Belo Horizonte, v. 15, n. 47, p. 797-827, jul./set. 2017 - ISSN 2175-5841 
A Exortação Apostólica Laudato Si’ chama o Planeta Terra de Casa comum (cf. FRANCISCO, 2015a). Por isso, a terra não pode ser privatizada nas mãos de alguns, obrigando miríades de agricultores a renunciar à vocação de "homens do campo" para viver nas periferias, como plantas desenraizadas. Um lavrador forçado a viver fora da terra assemelha-se a um exilado. Assim, a luta do MST corresponde à dos exilados da Bíblia, organizando-se para voltar à terra, dom de Deus aos pais, penhor de paz e felicidade.

6.5 Somado à conquista da terra, o MST pensa a organização do povo, para construir comunidades de irmãos e irmãs, que trabalham juntos e partilham o fruto do seu suor. O egoísmo e o individualismo da modernidade são ervas daninhas a serem combatidas. Manter vivo o ideal comunitário é fundamental no MST. A terra, longe de ser palco de conflitos e guerras, deve se tornar lugar da fraternidade, da partilha e do cuidado.

Os inimigos do MST fecham-se ao movimento, condenando-o com o apodo “comunista" ou "marxista". Assim, sentem-se autorizados a seguir adiante acumulando terras, violentando posseiros e pequenos proprietários e reduzindo seres humanos à escravidão, com a cumplicidade do poder público e das estruturas do Estado. Indivíduos incautos e sem discernimento são enganados por um discurso, cujo efeito consiste em manter a secular desigualdade social, num país com recursos suficientes para manter, com elevado padrão de dignidade, os mais pobres dentre seus filhos.

O MST, na luta para fazer acontecer a reforma agrária, sintoniza-se com o ideal bíblico de destino universal dos bens da criação. Acumular terra em detrimento de milhões de pessoas constitui-se em ofensa ao Criador. Lutar para que seja repartida com equidade e trabalhada em benefício de todos significa colaborar na obra da criação. Religião, Direitos Humanos e Direitos da Natureza estão, aí, implicados de maneira inextrincável! 
Os clamores dos povos indígenas, quilombolas, sem-terra e assentados, ribeirinhos e pescadores, produtores familiares e, em última análise, das cidades e da Terra sobem aos céus (cf. CNBB, 2014, p. 21-40). Um rastro da passagem de Deus pelas terras brasileiras será a superação da injustiça fundiária e a garantia de sua posse e uso por quem depende dela para trabalhar, sobreviver e cultivar as tradições ancestrais.

\section{Conclusão}

A luta do MST situa-se na utopia da "terra sem males", "sem violência, sem dores ou lágrimas (cf. Ap 21,1-17)”, na esperança de “"novos céus e nova terra, nos quais habitará a justiça' (cf. 2Pd 3,13)” (CNBB, 2014, p. 109)21. Desde a invasão portuguesa, o solo brasileiro tem sido sistematicamente aviltado e sua população, mormente, os mais pobres e indefesos, desrespeitada em seus direitos elementares. Como reação, a história é pontilhada de lutas para superar um regime de exploração que assume sempre novas feições. O MST insere-se nessa dinâmica, com organização e estratégias peculiares, lutando contra o latifúndio e o agrobusiness, na esperança de fazer acontecer a justiça no campo ${ }^{22}$.

Camponeses, agricultores e, especialmente, indígenas cultivam relações atávicas de respeito pela terra, à qual sua identidade sociocultural e religiosa está ligada. Pensá-los fora do habitat natural corresponde a condená-los à morte ou a viver desenraizados e sem identidade. A luta para que exerçam o direito de posse e usufruto da terra corresponde ao esforço para lhes garantir a dignidade de filhos e filhas do Deus Criador.

Deus passa na luta do MST para superar a desigualdade e a injustiça fundiárias. É uma das muitas formas de o Reino de Deus acontecer entre nós!

\footnotetext{
${ }^{21}$ Para compreender a expressão "terra sem males" (SUESS, 2002).

${ }^{22}$ Esta utopia parece estar longe de ser alcançada. Uma reportagem de 06/12/2016, intitulada Estudo mostra concentração de terras no Brasil, expressão máxima da desigualdade social, revela a face sombria da realidade fundiária, em nosso País (GONZALEZ, 2016). Entretanto, a luta continua!
}

Horizonte, Belo Horizonte, v. 15, n. 47, p. 797-827, jul./set. 2017 - ISSN 2175-5841 


\section{REFERÊNCIAS}

ALCÂNTARA Fo, J. L.; FONTES, R. M. O. A formação da propriedade e a concentração de terras no Brasil, Revista de História Econômica \& Economia Regional Aplicada, Juiz de Fora, v. 4, n. 7, p. 63-85, 2009.

ALMEIDA, Antonio A. de. A mística na luta pela terra. Revista Nera, Presidente Prudente, v. 8, n. 7, p. 22-34, 2005. Disponível em:

<http://revista.fct.unesp.br/index.php/nera/article/view/1449/1426>. Acesso em: 26 ago. 2017.

AZEVEDO, M. “Quantos eram? Quantos serão?”, 2000. Disponível em: <https://pib.socioambiental.org/pt/c/no-brasil-atual/quantos-sao/quantos-eramquantos-serao>. Acesso em: 16 dez. 2016.

BRANDFORD, S.; ROCHA, J. Rompendo a cerca - a história do MST. São Paulo: Casa Amarela, 2004.

BRUEGGEMANN, W. A terra na Bíblia - dom, promessa e desafio. São Paulo: Paulinas, 1986.

CARAVIAS, J. L.; BARROS, M. Teologia de la Tierra - Los problemas de la tierra vistos desde la fe. CEPAG: Asunción, 1990.

CNBB. A Igreja e a questão agrária brasileira no início do século XXI. São Paulo, Paulinas, 2014 (Col. Documentos da CNBB 101).

CODINA, V. Los caminhos del Oriente Cristiano. Iniciación a la teologia oriental. Maliaño: Sal Terrae, 1997.

CODINA, V. Teologia Simbólica da Terra. CPT: Goiânia, 1995.

COMISSÃO PASTORAL DA TERRA. CPT: pastoral e compromisso. Petrópolis-Goiânia: Vozes-CPT, 1983.

COSME, C. M. Reforma Agrária no Brasil do século XXI: Qual reforma agrária? Boletim DATALUTA, São Paulo, n. 106, p. 1-25, 2016. Disponível em:

<http://www2.fct.unesp.br/nera/artigodomes/10artigodomes_2016.pdf.>. Acesso em: 26 ago. 2017.

DAVIES, E. W. Terra: seus direitos e privilégios. In: CLEMENTS, R. E. O mundo do Antigo Israel - perspectivas sociológicas, antropológicas e políticas. São Paulo: Paulus, 1995. Cap. 16, p. 335-352.

FERNANDES, B. M. A formação do MST no Brasil. Petrópolis: Vozes, 2000.

GONZALEZ, Amelia. Estudo mostra concentração de terras no Brasil, expressão máxima da desigualdade social. G1, Brasil, o6 dez. 2016. Disponível em:

<http://g1.globo.com/natureza/blog/nova-etica-social/post/estudo-mostra-concentracaode-terras-no-brasil-expressao-maxima-da-desigualdade-social.html>. Acesso em: 27 ago. 2017.

Horizonte, Belo Horizonte, v. 15, n. 47, p. 797-827, jul./set. 2017 - ISSN 2175-5841 
INSTITUTO SOCIOAMBIENTAL, s.d. População indígena no Brasil. Disponível em: <https://pib.socioambiental.org/pt/c/o/1/2/populacao-indigena-no-brasil > . Acesso em: 16 dez. 2016.

LAUREANO, D. dos S. O MST e a Constituição - Um sujeito histórico na luta pela reforma agrária no Brasil. São Paulo: Expressão Popular, 2007.

MEINCKE, S. Luta pela terra e Reino de Deus. São Leopoldo: Sinodal, 1988.

MENEZES NETO, A. J. de. A ética da teologia da libertação e o espírito do socialismo no MST. Belo Horizonte: Editora UFMG, 2012.

MESQUITA, R. G. de M.; NASCIMENTO, G. W. do. Educação do MST e crise do paradigma moderno de ciência. Revista Brasileira de Educação, Rio de Janeiro, v. 19, n. 59, p. 1077-1099, 2014.

OLIVEIRA, A. A. de. Formação e trabalho no Movimento Sem Terra (MST): processos de resistência do campesinato. Belo Horizonte, 2014, 231 f., Dissertação (Mestrado em Educação) - Faculdade de Educação, Universidade Federal de Minas Gerais.

PAPA FRANCISCO. Carta Encíclica Laudato Si' sobre o cuidado da casa comum. São Paulo: Paulus; Loyola, 2015a.

PAPA FRANCISCO. Discurso do Papa aos participantes do II Encontro Mundial dos movimentos populares. Santa Cruz de la Sierra - Bolívia, 2015b. Disponível em: <http://pt.radiovaticana.va/news/2015/o7/10/discurso_do_papa_aos_movimentos_pop ulares_(texto_integral)/1157336>.Acesso em: 24 mai. 2016.

PAPA FRANCISCO. Discurso do Papa Francisco aos participantes no I Encontro Mundial dos Movimentos Populares. Roma, 28 out. 2014. Disponível em: <https://w2.vatican.va/content/francesco/pt/speeches/2014/october/documents/papafrancesco_20141028_incontro-mondiale-movimenti-popolari.html >. Acesso em: 24 mai. 2016.

PAPA FRANCISCO. Discurso do Papa Francisco aos participantes do III Encontro Mundial dos Movimentos Populares. Roma, o5 nov. 2016. Disponível em:

<http://w2.vatican.va/content/francesco/pt/speeches/2016/november/documents/papafrancesco_20161105_movimenti-popolari.html>. Acesso em: 16 dez. 2016.

PINTO, L. H. La influencia de la Comisión Pastoral de la Tierra (CPT) en la formación del Movimiento de los Trabajadores Rurales Sin Tierra (MST): breve análisis teóricodocumental del papel da la religión en los conflictos sociales en Brasil (1954-1984). Revista de Estudios Sociales, Bogotá, v. 51, n. 1, p. 76-88, 2015.

REIS, R. R. O direito à terra como um direito humano: a luta pela reforma agrária e o movimento de direitos humanos no Brasil. Lua Nova: Revista de Cultura e Política, São Paulo, v. 86, p. 88-122, 2012. 
ROCHA, R. J. de S.; CABRAL, J. P. Aspectos históricos da questão agrária no Brasil. Revista Produção Acadêmica - Núcleo de Estudos Urbanos Regionais e Agrários, Porto Nacional, v. 2, n. 1, p. 75-86, 2016. Disponível em: <file:///D:/Downloads/2963265-15499-1-10-20161129.pdf>. Acesso em: 26 ago. 2017.

RODRIGUES, Alex. MST volta a ocupar fazendas e bloquear estradas para cobrar reforma agrária. EBC Agência Brasil, Brasília/DF, 17 abr. 2017. Disponível em:

<http://agenciabrasil.ebc.com.br/geral/noticia/2017-04/mst-volta-ocupar-fazendas-ebloquear-estradas-para-cobrar-reforma-agraria >. Acesso em: 26 ago. 2017.

STEDILE, J. P.; FERNANDES, B. M. Brava gente - A trajetória do MST e a luta pela terra no Brasil. $3^{\text {a }}$ reimpr. São Paulo: Ed. Fundação Perseu Abramo, 1996.

SUESS, Paulo. Encontro e desencontro na busca da “Terra sem Mal”, 2002. Disponível em:

<http://www.missiologia.org.br/cms/UserFiles/cms_artigos_pdf_50.pdf>. Acesso em: 26 ago. 2017.

THOMAZ JÚNIOR, A. Povoando o território da luta pela terra e pela reforma agrária no Brasil contemporâneo. Revista Pegada Eletrônica, Presidente Prudente, v. 11, n. 2, p. 135, 2010. Disponível em:

<http://revista.fct.unesp.br/index.php/pegada/article/view/1303/1299>. Acesso em: 26 ago. 2017.

VITÓRIO, J. Monarquia e profetismo: duas instituições em conflito. 1Rs 21,1-19 - A vinha de Nabot. Estudos Bíblicos, Petrópolis, s.v., n. 88, p. 82-95, 2005.

ZEN, E. T. Luta pela terra e o nascimento do MST: lições de cidadania. Redes Revista Capixaba de Filosofia e Teologia, Vitória, v. 2, n. 4, p. 209-221, 2005.

ZWETSCH, R. Terra, lugar e espaço: a luta dos pobres por cidadania e dignidade no Brasil desde uma perspectiva teológica. Diálogo, Canoas, v. 17, n. 2, p. 71-96, 2010. 